Ks. Marian ZAJĄC

(Lublin, KUL)

\title{
EUCHARYSTIA JAKO CENTRUM CELEBRACJI CHRZEŚCIJAŃSKIEJ W UJECCIU KATECHETYCZNEJ SZKOLY ALEKSANDRYJSKIEJ
}

W swojej pierwszej encyklice o wierze Lumen fidei Ojciec Święty Franciszek przywołuje na początku św. Justyna Męczennika oraz św. Klemensa Aleksandryjskiego. Aby wprowadzić człowieka w wielki temat wiary, posługuje się wypowiedzią św. Klemensa stwierdzając: „Chrześcijanie, świadomi, jak wielki horyzont otwiera przed nimi wiara, nazwali Chrystusa prawdziwym słońcem, «którego promienie dają życie», ${ }^{1}$. Tym samym kontynuuje dzieło swojego poprzednika, który w dokumencie na Rok wiary napisał: „Rok Wiary «będzie też dobrą okazją, by z większym zaangażowaniem celebrować wiarę w liturgii, a zwłaszcza w Eucharystii»" ". Papież zachęca wszystkich wiernych do brania udziału w Eucharystii świadomie, aktywnie i owocnie, aby stawać się autentycznymi świadkami Pana. Wyraził także pragnienie, aby rok poświęcony celebrowaniu wiary „,rozbudził w każdym wierzącym aspirację do wyznawania wiary w pełni i z odnowionym przekonaniem, z ufnością i nadzieją"3. Nawiązując do soborowej konstytucji o liturgii ${ }^{4}$ nakazał, ,by z większym zaangażowaniem celebrować wiarę w liturgii, a zwłaszcza w Eucharystii, która «jest szczytem, do którego zmierza działalność Kościoła, i zarazem jest źródłem, z którego wypływa cała jego moc»»"s.

Poszukując źródła inspiracji dla obecnie realizowanego katechetycznego przygotowania dzieci do rozumienia i celebrowania Eucharystii, które odbywa się w publicznych szkołach, chcemy zaczerpnąć z nauczycielskiego potencjału

\footnotetext{
${ }^{1}$ Franciscus Pontifex, Litterae encyclicae „Lumen fidei” 1, thum. pol.: Ojciec Świety Franciszek, Encyklika „Lumen fidei”. O wierze do biskupów prezbiterów i diakonów do osób konsekrowanych $i$ wszystkich wiernych świeckich, Kraków 2013, Wydawnictwo „M”; por. Clemens Alexandrinus, Protrepticus 9, 84, 2, GCS 12, 63.

2 Benedictus XVI, Litterae Apostolicae „Porta fidei” 9, thum. pol.: Benedykt XVI, List Apostolski w formie Motu Proprio „Porta fidei” ogłaszajacy Rok Wiary, Tarnów 2013, Wydawnictwo „Biblos”.

${ }^{3}$ Tamże.

${ }^{4}$ Concilium Vaticanum II, Constitutio „Sacrosanctum Concilium” (4 XII 1963) 10, thum. pol.: Sobór Watykański II. Konstytucje. Dekrety. Deklaracje, Poznań 2002, 52.

${ }^{5}$ Benedictus XVI, Litterae Apostolicae „Porta fidei” 9.
} 
starożytnej Aleksandryjskiej Szkoły Katechetycznej ${ }^{6}$. Istnieje bowiem pilna potrzeba powrotu do źródeł, w obliczu wielu współczesnych zagrożeń dla inicjacji chrześcijańskiej.

Na początku można jednak zadać pytanie o sens sięgania do przeszłości w epoce multimediów i elektroniki? Odpowiedzi na to pytanie udzielił katechetom Benedykt XVI stwierdzając: „W liturgii jaśnieje tajemnica paschalna, poprzez którą sam Chrystus pociaga nas do siebie i wzywa do komunii. W Jezusie, jak miał zwyczaj mówić św. Bonawentura, kontemplujemy «piękno i blask początków»" ". W czasie, kiedy istnieje bezkrytyczny kult postępu, chcemy zaczerpnąć z duchowego źródła początków chrześcijaństwa i nauki o Eucharystii ${ }^{8}$.

\section{EUCHARYSTIA - TAJEMNICA CELEBROWANA}

W starożytności chrześcijańskiej Eucharystia stanowiła najwspanialszą wizję życia osób wierzących w Chrystusa. Księga Dziejów Apostolskich świadczy o tym, że wśród pierwszych chrześcijan, którzy przyjęli sakrament chrztu, wszyscy trwali potem na łamaniu chleba i na modlitwie dziękczynnej. Przy eucharystycznych ceremoniach były obecne całe rodziny, w tym także małe dzieci. Setnik Korneliusz i strażnik więzienia w Filippi przyjmowali chrzest wraz z całym swym domem (zob. Dz 16, 33).

\footnotetext{
${ }^{6} \mathrm{Na}$ ten temat por. m.in. Th. Camelot, L'Eucharistie dans l'École d'Alexandrie, „Divinitas” 1 (1957) 71-92; J. Betz, Die Eucharistie in der Zeit der griechischen Väter, Bd. I/1, Freiburg 1955, 95-96, 283-284; tenże, HDG IV 4a, 68-69; G. Bareille, Eucharistie d'après les Pères, DThC V 11351141, 1162-1172; Ojcowie Kościoła Wschodniego o Eucharystii, oprac. M. Starowieyski, Katowice - Ząbki 2005, 29-31 (Orygenes), 54-61 (Cyryl Aleksandryjski).

${ }^{7}$ Benedictus XVI, Messaggio ai partecipanti al II Congresso Mondiale dei movimenti ecclesiali e delle nuove communità (22 V 2006), AAS 98 (2006) 463, lub Insegnamenti di Benedetto XVI, II/1, 663, tłum. pol.: Benedykt XVI, Przesłanie do uczestników II Światowego Kongresu Ruchów Kościelnych i Nowych Wspólnot, OsRomPol 2006, nr 6(285), 7.

${ }^{8}$ Konferencja Episkopatu Polski, Dyrektorium katechetyczne Kościoła katolickiego w Polsce, Kraków 2001, 106; o Eucharystii w starożytności chrześcijańskiej zob. m.in.: J. Solano, Textos Eucaristicos primitivos, I-II, Madrid 1954; Ojcowie Kościoła Wschodniego i Zachodniego o Eucharystii, I-II, oprac. M. Starowieyski, Katowice - Ząbki 2005; Pokarm nieśmiertelności. Eucharystia w życiu pierwszych chrześcijan, red. W. Myszor - E. Stanula, Katowice 1987; Eucharystia pierwszych chrześcijan. Ojcowie Kościoła nauczaja o Eucharystii, red. M. Starowieyski, OŻ VII, Kraków 1987; J. Gliściński, Eucharystia w nauczaniu Ojców Kościoła, HD 56 (1987) z. 2, 88-94; E. Hebda, Życie eucharystyczne w pierwszych wiekach Kościoła, „Głos Karmelu” 20 (1951) 49-55; J. Kopeć, Eucharystia w życiu pierwszych wspólnot chrześcijańskich, „Premislia Christiana” 6 (1993-1995) 16-32; S. Longosz, Cześć Eucharystii w starożytności chrześcijańskiej, w: Jezus eucharystyczny, red. M. Rusecki - M. Cisło, Lublin 1997, 61-80; A. Młotek, Eucharystia w nauce wczesnochrześcijańskich pisarzy i synodów, w: Eucharystia, red. J. Krucina, Wrocław 1987, 179-198; E. Ozorowski, Nauka o Eucharystii w wypowiedziach Urzędu Nauczycielskiego Kościoła, AK 75 (1983) t. 101, 197-212; M. Starowieyski, Eucharystia pierwszych chrześcijan, OŻ VII, Kraków 1987, 9-30; J. Miazek, Msza święta pierwszych chrześcijan, tamże, s. 31-51; S. Longosz, Polskojęzyczna bibliografia o Eucharystii w Kościele starożytnym, VoxP 16 (1996) z. 30-31, 525-532.
} 
$\mathrm{Na}$ duszpasterskie przygotowanie do pełnego przeżywania świętej Eucharystii miała później wpływ także Reformacja i polemiki religijne z protestantami. Wtedy to zrodził się zwyczaj urządzania oddzielnej uroczystości pierwszokomunijnej dla podkreślenia znaczenia Eucharystii w życiu wierzącego człowieka. Po Soborze Trydenckim zaczyna się dominacja Katechizmu Rzymskiego oraz opartych na nim zaleceń, a wśród nich - trudny egzamin ze znajomości prawd wiary przed I Komunią świętą. Trudności ze zdawaniem tych egzaminów doprowadziły do przesunięcia inicjacji eucharystycznej na 14 rok życia, a nawet lata późniejsze ${ }^{9}$. W XVII stuleciu na przesunięcie wieku przyjęcia I Komunii świętej miał także wpływ jansenizm, który Eucharystię traktował jako nagrodę za święte życie; stała się więc ona dostępna tylko dla wybranych, a nie dla wszystkich, jak tego pragnął Zbawiciel ${ }^{10}$.

Wydaje się, że kluczowe znaczenie posiada kształtowanie wspólnotowej świadomości eucharystycznej, tak ze względu na istotę Eucharystii, jak również na uczestnictwo w niej, stanowiące centrum życia Kościoła i każdego chrześcijanina. Ciagle jednak przeważa wśród dzieci i młodzieży mentalność nieomal wyłącznie osobistego spotkania z Panem z zagubieniem wymiaru wspólnotowego. Tymczasem w Eucharystii Kościół urzeczywistnia się w dzisiejszym świecie, a jej sprawowanie przyczynia się do tego, że wierni mogą swym życiem wyrażać umiłowanie tej tajemnicy; w niej dokonuje się i ujawnia prawdziwa jedność ludu Bożego. Zadaniem zatem duszpasterzy jest podkreślanie, że ,,przez pamiątkę Pana, sprawowaną według Jego woli, wyraża się i sprawuje jedność wszystkich w Niego wierzących" ${ }^{11}$. Sprawowaniu Eucharystii winien towarzyszyć ból z powodu odejścia od uczestnictwa wielu ochrzczonych, a także modlitwa ,ażeby wszyscy uczniowie Chrystusa z każdym dniem coraz głębiej pojmowali tajemnicę Eucharystii i tak ją sprawowali, by stawszy się uczestnikami Ciała Chrystusa, tworzyli jedno ciało (1Kor $10,17)$ połączone takimi więzami, którymi On sam chciał je połączyć"12. Wspólna Eucharystia ukazuje się jako cel dążeń katechetycznych. Przez katechizowanych powinien być bardziej w Eucharystii zauważony wymiar pojednania z Bogiem i braćmi ${ }^{13}$, jako owoc uobecnienia Ofiary Krzyża, źródła zbawienia i pojednania dla wszystkich ludzi.

\footnotetext{
${ }^{9}$ Por. M. Rusiecki, Przedmiot katechezy potrydenckiej w Polsce (1566-1699), Lublin 1996, 31.

${ }^{10}$ Por. W. Pawlik. Katechizmy w Rzeczpospolitej od XVI do XVIII wieku, Lublin 2010, 7.

${ }^{11}$ Por. Concilium Vaticanum II, Constitutio „Lumen gentium” (21 XI 1964) 3, thum. pol.: Sobór Watykański II. Konstytucje. Dekrety. Deklaracje, s. 105; zob. H. Pietras, Jedność wspólnoty kościelnej jako owoc Eucharystii w nauczaniu pierwszych Ojców, ŚSHT 19-20 (1986-1987) 5-12; E. Staniek, Wspólnotowy charakter Eucharystii wedtug ,Didache”, w: Eucharystia źródtem życia, Kraków 1987, 169-176.

${ }^{12}$ Por. L. Bouyer, Eucharist, theology and spirituality of the Eucharistic Prayer. Notre Dame, Indiana, 1968, 84-85.

${ }^{13}$ Por. Joannes Paulus II, Adhortatio Apostolica „Reconciliatio et poenitentia” (2 XII 1984) 7 , thum. pol.: Jan Paweł II, Posynodalna adhortacja apostolska o pojednaniu i pokucie $w$ dzisiejszym
} 
Również w naszych czasach istnieje wiele faktycznych przeszkód w prowadzeniu pełnej inicjacji do tego sakramentu i jego godnej celebracji. Szukając właściwych inspiracji w tym obszarze warto się odwołać do pierwszych wieków chrześcijaństwa, gdzie nauczanie o znaczeniu Eucharystii posiadało również walor bliskości naocznych świadków Chrystusa.

\section{KATECHETYCZNA SZKOŁA ALEKSANDRYJSKA W SŁUŻBIE WSPÓŁCZESNEJ SZKOŁY EUCHARYSTII}

Celebrowanie Eucharystii było dla uczniów Chrystusa zupełnie nowym i niespodziewanym darem. Chcąc go godnie przyjąć musieli się nauczyć korzystać z niego, a następnie za niego dziękować w myśl znaczenia słowa

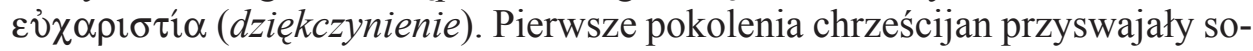
bie najpierw tę tajemnicę, a potem wypracowywały sposoby korzystania z jej duchowego potencjału. Kościół starożytny stworzył nową tradycję przepowiadania, kultu i życia ${ }^{14}$. Zerwał więzy ze wspólnotą synagogalną, a zorganizował własny kult oparty na Eucharystii (stół Słowa Bożego i stół łamania chleba). Zdecydowanie również odciął się od podstawowych hebrajskich zwyczajów jak np. obrzezania, a rozpoczął praktykowanie bratniej miłości. Oddzielenie nowego stylu celebracji od istniejącego wcześniej w synagodze, bez zagubienia jego istoty, było zadaniem pilnym i nieodzownym. Stopniowo przeobrażał się też sposób pojmowania daru Eucharystii oraz mozolnie dojrzewał sposób uczestniczenia w niej ${ }^{15}$.

Wiele nowego do nauki na temat Eucharystii wniosła tzw. Katechetyczna Szkoła Aleksandryjska ${ }^{16}$. Twórcami szkół teologicznych w starożytności byli przeważnie wybitniejsi chrześcijańscy katecheci i nauczyciele, którzy w ten sposób chcieli przyczynić się do ewangelizacji świata. Roman Murawski stwierdza, że temat szkoły aleksandryjskiej prowadzonej ,najpierw przez Pantena, potem przez Klemensa, a następnie już z mandatu biskupa Demetriusza przez Orygenesa, wzbudzał i nadal wzbudza wielkie zainteresowanie i dyskusje" ${ }^{17}$. Pominiemy tu dyskusje na jej temat, a skupimy się na jej przekazie teologicznym o Eucharystii. Właściwe zaś zrozumienie znaczenia Eucharystii i jej celebracji w ujęciu tej szkoły, zdaniem Marino Qualizzy, ma swój początek w teologicznej myśli jej założycieli i jej najwybitniejszych przedstawicieli w osobach Klemensa $(† 212)$ i Orygenesa $(† 254)$ oraz św. Atanazego (†373)

posłannictwie Kościoła „Reconciliatio et poenitentia”, w: Adhortacje Ojca Świętego Jana Pawła II, t. 1, Kraków 1996, 191-267.

${ }^{14}$ Por. H. Walednsfels, O Bogu, Jezusie Chrystusie i Kościele - dzisiaj, thum. A. Paciorek, Katowice 1993, 434.

${ }^{15}$ Por. A. Żurek, Wczesnochrześcijańska pobożność eucharystyczna, „Currenda” 155 (2005) 331-339.

${ }^{16}$ Por. Camelot, L'Eucharistie dans l'École d'Alexandrie, s. 71-92.

${ }^{17}$ R. Murawski, Historia katechezy, cz. 1: Katecheza w pierwszych wiekach, Warszawa 2011, 178. 
i św. Cyryla Aleksandryjskiego († 444), u którego teologia eucharystyczna Aleksandryjczyków osiągnęła szczyt. Twórcy tej szkoły utrzymywali, że „chrześcijaństwo polega na uczestnictwie w Boskim Logosie. Zbliżyć się zaś do Niego można za pośrednictwem człowieczeństwa Jezusa, poprzez główną drogę Eucharystii" "18. Zasadniczą uwagę Aleksandryjczycy poświęcali zawsze odwiecznemu Słowu, ponieważ do Niego, ich zdaniem, zdąża cała historia: Ono jest punktem docelowym każdego ludzkiego oczekiwania i pragnienia, będąc także początkiem bytu. Aby zaś przybliżyć ich poglądy o Eucharystii, przytoczymy po kilka ich konkretnych wypowiedzi na jej temat.

Klemens Aleksandryjski wskazywał, że w rozumieniu Eucharystii przewodnikiem jest Jezus Chrystus, który najpierw zachęca do jej zgłębienia, potem wychowuje, aby w końcu o niej uczyćc ${ }^{19}$. Choć w swoich wielu wypowiedziach zdaje się odrzucać wszelkie ofiary, w tym domyślnie i ofiarę eucharystyczną, jako niepotrzebne $\mathrm{Bogu}^{20}$, to jednak ma on w nich na myśli krwawe ofiary pogańskie, w czym zgadza się z chrześcijańskimi apologetami; mówi jednak o „ofierze Kościoła, którą jest mowa wznosząca się, od dusz świętych, jak dym ofiarny ku niebu"21. Gdzie indziej krytykując heretyków, że wbrew regule Kościoła, który w liturgii [eucharystycznej] tak jak ongiś Melchizedek używa chleba i wina, używają samej wody, uznaje w Eucharystii ofiarę, ale widzi w niej również pokarm dla tych, którzy mają wiarę:

„Melchizedek, król Salemu, kapłan Boga Najwyższego (Rdz 14, 18), który ofiaruje wino i chleb, uświęcony pokarm, co stanowi prawzór dla Eucharystii"'22.

Logos, jak troskliwa matka lub wychowawca, zachęca nas, byśmy spożywali w Eucharystii Jego Ciało:

„Logos jest dla niemowlęcia wszystkim, bo Ojcem, Matka, Wychowawcą i Żywicielem. «Jedzcie moje Ciało i pijcie moją Krew». Nam, małym dzieciom, nie brakuje więc niczego koniecznego do wzrostu. O niezwykła tajemnico! Pan poleca, byśmy się wyzbyli dawnego, cielesnego zepsucia, podobnie jak dawnego pożywienia. Przyjmując nowy tryb życia w Chrystusie mamy, na ile to możliwe, przyjąć Zbawiciela i umieścić Go w swoim sercu ,

${ }^{18}$ M. Qualizza, Inicjacja chrześcijańska, tłum. M. Stewart, Kraków 2002, 127.

${ }^{19}$ Por. S. Łucarz, Inicjacja w ujęciu Klemensa Aleksandryjskiego, w: Kondycja chrześsijaństwa dzisiaj a inicjacja chrześcijaństwa starożytności, red. B. Górka, Gdańsk 2005, 107-109. Syntezę jego nauki o Eucharystii zob. Bareille, DThC V 1135-1136.

${ }^{20}$ Por. Clemens Alexandrinus, Stromata VII 3, 14, 5, GCS 17, 11, thum. J. Niemirska-Pliszczyńska: Klemens Aleksandryjski, Kobierce, II, Warszawa 1994, 227: „Z tej przyczyny słusznie ofiar nie składamy Bogu, który przecież niczego sam nie potrzebuje, a wszystkiego wszystkim użyczał, ale sławimy Tego, który sam siebie złożył na ofiarę, oraz sami siebie składamy w ofierze, aby osiagnąć coraz doskonalszy stan nieodczuwania potrzeb i namiętności”.

${ }^{21}$ Tamże VII 6, 32, 4, GCS 17, 24, tłum. J. Niemirska-Pliszczyńska, II 242.

${ }^{22}$ Tamże IV 25, 161, 3, GCS 52, 319, tłum. J. Niemirska-Pliszczyńska, I 387. 
byśmy pokonywali swoje cielesne namiętności. Jeśli tego nie pojmujesz, to może wolisz bardziej prosto? Posłuchaj więc. Duch Święty wskazuje nam alegorycznie ciało, gdyż przez Niego zostało ono stworzone. Krew to Logos rozlany na nasze życie. Pan jako połączenie tych dwojga jest pokarmem niemowląt jako Duch i Logos, pokarm, którym jest Pan Jezus. Jest On Logosem pochodzącym od Boga, Duchem, który przyjął ciało. Jest to uświęcone ciało z nieba"23.

W pierwszej części powyższej wypowiedzi Klemens prezentuje Eucharystię jako nowy pokarm, który pozwala nam z czystym sercem przyjmować Chrystusa i spowodować, by zamieszkał w naszych sercach. W drugiej zaś daje jej alegoryczne wyjaśnienie tym, którzy nie zrozumieli poprzedniej literalnej interpretacji.

Gdzie indziej znów Klemens rozróżnia między krwią ludzką a krwią eucharystyczną Chrystusa, nazywając tę drugą mieszaninę napoju i Logosu Eucharystią. W ciele i w duszy człowieka, który ją pije, ta krew eucharystyczna ożywia wiarę oraz uświęca i prowadzi do nieśmiertelności:

„Jest to podwójnie krew Pana, gdyż z jednej strony krew z Jego ciała, którą jesteśmy wykupieni ze zguby, z drugiej duchowa, którą zostaliśmy namaszczeni. Na tym polega picie krwi Chrystusa, by uczestniczyć w nieśmiertelności Pana. Jak siłą Logosu jest Duch, tak krew jest siłą ciała. Tak jak wino miesza się z woda, tak duch z człowiekiem. Jak mieszanina wina z wodą żywi wiarę, tak ta $\mathrm{z}$ duchem prowadzi do nieśmiertelności. Połączenie obu, a więc napoju i Logosu nazywa się Eucharystią sławioną jako piękny dar łaski. Uczestniczący w niej uświęcają zgodnie $\mathrm{z}$ wiarą ciało i duszę"24.

W powyższej wypowiedzi Klemensa dostrzegamy też jego potwierdzenie prawdziwej obecności Chrystusa we Krwi eucharystycznej oraz wyraźne stwierdzenie, że materią Eucharystii jest woda i wino, a jej owocami - uświęcenie cielesne i duchowe oraz udział w nieśmiertelności Chrystusa.

Już z powyższych wypowiedzi Klemensa widać, że używa on często terminu ,eucharystia” ( $(\dot{\chi} \chi \alpha \rho \imath \sigma \tau i \alpha)$; w swoich pismach użył go, jak zauważa ks. F. Drączkowski, 21 razy i to głównie w dwóch grupach znaczeniowych: 1. na oznaczenie: modlitwy dziękczynnej, postawy dziękczynienia, wdzięczności względem Boga lub człowieka - 17 razy; 2. na oznaczenie pokarmu eucharystycznego, czyli Ciała i Krwi Chrystusa oraz ofiary Nowego Testamentu, której figura jest ofiara Melchizedeka - 4 razy, co stanowi zaledwie 19\% jego całościowego użycia ${ }^{25}$. Pokarm [chleb] eucharystyczny nazywany był przez

${ }^{23}$ Clemens Alexandrinus, Paedagogus I 6, 42, 3 - 42, 2, GCS 12, 115, tłum. M. Szarmach: Klemens Aleksandryjski, Wychowawca, Toruń 2012, 43-44.

${ }^{24}$ Tamże II 2, 19, 4 - 20, 2, GCS 12, 167-168, tłum. M. Szarmach, s. 95-96.

${ }_{25}$ Por. F. Drączkowski, Termin ,eucharystia” w pismach Klemensa AleAleksandryjskiego, VoxP 7 (1987) z. 12-13, 73-86, spec. s. 76. 
niego także: „chlebem niebian”, „mlekiem niebiańskim”, „mlekiem miłości”, „pokarmem niemowląt”, ,chlebem Bożym”, ,pokarmem Pańskim”, czy „winnym gronem” ${ }^{26}$. Nie trudno zauważyć, że termin „eucharystia” używany był przez niego najczęściej w podstawowym jego znaczeniu ${ }^{27}$ - na oznaczenie wdzięczności i postawy dziękczynnej jako stałej dyspozycji psychicznej, zapewne też pod wpływem św. Pawła, który w tym znaczeniu użył go 8 razy $^{28}$.

O wiele pełniej o Eucharystii i jej celebracji uczył najwybitniejszy przedstawiciel Szkoły Aleksandryjskiej oraz największy egzegeta i katecheta III wieku - Orygenes ${ }^{29}$. Naukę o Eucharystii uważał on, jak stwierdza S. Kalinkowski, za najgłębszą tajemnicę, i to w dwojakim sensie: jako naukę ezoteryczną dostępną wyłącznie dla wtajemniczonych ${ }^{30}$ oraz jako naukę, trudną do zrozumienia i wyjaśnienia ${ }^{31}$. Przy takiej postawie nie dziwi nas, że mimo wielkości swego umysłu nie pozostawił nam w swoich pismach zwartego i jednolitego wykładu nauki o niej, choć z rozrzuconych na jej temat jego wypowiedzi wynika jasno, że przyjmował on rzeczywistą obecność Chrystusa w postaciach eucharystycznych, ofiarny charakter Eucharystii i jej uświęcające działanie. Jeśli chodzi o rzeczywistą obecność Chrystusa w postaciach eucharystycznych, to m.in. w nawiązaniu do J 6, 53-55 stwierdza wyraźnie:

" «Ciało moje jest prawdziwym pokarmem, a krew moja jest prawdziwym napojem» (J 6, 55). Ponieważ zatem Jezus cały jest czysty pod każdym względem, przeto całe Jego ciało jest pokarmem, a cała Jego krew jest napojem, bo wszelkie Jego dzieło jest święte, a każde Jego słowo prawdziwe. A więc dlatego Jego ciało jest prawdziwym pokarmem, a krew Jego prawdziwym napojem. Albowiem ciałem i krwią swojego Słowa poi On i karmi cały rodzaj ludzki jak czystym pokarmem i napojem"s2.

${ }^{26}$ Por. tamże, s. 73.

${ }^{27}$ Por. S. Longosz, Nazwa ,eucharystia”. Okres przedchrześcijański, VoxP 16 (1996) z. 30-31, 349-363.

${ }^{28}$ Por. F. Drączkowski, Eucharystia - nieustanne dziękczynienie według Klemensa Aleksandryjskiego, w: Eucharystia - miłość i dziękczynienie = Homo Meditans IX, red. W. Słomka - A.J. Nowak, Lublin 1992, 43-51.

${ }^{29}$ Por. S. Kalinkowski, Orygenes o Eucharystii, w: Pokarm nieśmiertelności. Eucharystia w życiu pierwszych chrześcijan, s. 64-75; Th. Camelot, Eucharistie dans l'Ecole d'Alexandrie, s. 73-85; A. Struckmann, Eucharistische Texte griechischer Väter aus der Zeit vor dem Konzil von Nicea, Paderborn 1926, 15-24; G. Bareille, DThC V 1137- 1139; J. Betz, Die Eucharistie in der Zeit der griechischen Väter, Bd. I/1, Freiburg 1955, 93-95, 118-120, 279-281; tenże, HDG IV/4a, 47-52; J.M. Szymusiak, SWP 482-483. 30.

${ }^{30}$ Por. Origenes, In Leviticum hom. 9, 10, PG 12, 523C.

${ }^{31}$ Por. In Numeros hom. 5, 1, PG 12, 603C, thum. S. Kalinkowski, PSP 34/1, 54: „Gdy chodzi o Eucharystię, o wyjaśnienie jej rytuału albo o słowa, gesty porządek, pytania i odpowiedzi związane z obrządkiem chrztu: któż może łatwo wyjaśnić ich znaczenie?”, por. S. Kalinkowski, Orygenes o Eucharystii, s. 64 .

${ }^{32}$ In Leviticum hom. 7, 5, PG 12, 486D-487A, thum. S. Kalinkowski, PSP 31/2, 96. 
Zestawiając zaś Paschę z Eucharystią stwierdza:

„Jeśli zaś wstąpisz wraz z Nim [do górnej komnaty], aby świętować Paschę, [Jezus] daje ci kielich Nowego Przymierza, daje ci chleb błogosławieństwa, udziela ci swego ciała i swojej krwi”33

\section{Podobnie też uczy w Komentarzu do Pieśni nad pieśniami:}

„Chrystus staje się wszystkim dla poszczególnych zmysłów ich duszy. Oto nazywa się «prawdziwą światłością» $(1 \mathrm{~J} 2,8)$, aby oczy duszy mogły zostać czymś oświecone; nazywa się «Słowem» $(\mathrm{J} 1,1)$, aby uszy miały czego słuchać; nazywa się «chlebem życia» $(\mathrm{J} 6,35)$, aby smak duszy miał co kosztować" 34 .

Orygenes mówi tu wprawdzie, że Chrystus tylko „zwie się” chlebem żywym, a nie - że nim ,jest”, ale kilka linijek wcześniej nawiązując do J 6, 55 stwierdza wyraźnie: „Chrystus [...] jest chlebem i udziela życia”35.

Chrystus, według Orygenesa, jest rzeczywiście obecny w chlebie eucharystycznym, który staje sie Jego ciałem, dzięki modlitwie kapłańskiej:

„Chleby ofiarne [...] przez modlitwę stają się ciałem świętym i uświęcającym tych, którzy go spożywają w stosownym celu" ${ }^{\text {"36. }}$

Orygenes, jak zauważa S. Kalinkowski, nie nazywa nigdy wprost Eucharystii ofiarą (thysia), choć z kontekstu kilku jego wypowiedzi wynika, że ją uważał również za ofiarę. Wynika to m.in. z jego thumaczenia nazwy Betlejem jako Domu Chleba i traktowania go za symbol Kościoła, w którym codziennie sprawuje się ofiarę eucharystyczną:

„Otóż «Betlejem» znaczy «Dom Chleba», a dokąd mieli spieszyć pasterze po ogłoszeniu pokoju, jeśli nie do duchowego domu niebiańskiego chleba Chrystusowego, to znaczy do Kościoła, gdzie codziennie w mistyczny sposób ofiarowywany jest «chleb, który zstapił z nieba» $(\mathrm{J} 6,51)$ i daje życie światu? To Chrystus jest «chlebem żywym, który zstapił z nieba i został dany za życie świata», jak On sam mówi w Ewangeliach"37.

Podobnie nawiązując do terminu „eucharystia”, oznaczającego wdzięczność, mówi w swej apologii Przeciw Celsusowi o chlebie eucharystycznym jako o ofierze dziękczynnej, odpowiadając na jego zarzut, że chrześcijanie nie

${ }^{33}$ In Jeremiam hom. 19, 13, PG 13, 489C, thum. S. Kalinkowski, PSP 30, 167.

${ }^{34}$ Commentarius in Cantica canticorum II 9, 12, SCh 375, 442, thum. S. Kalinkowski: Orygenes, Komentarz do Pieśni nad Pieśniami, Kraków 1994, 117.

${ }^{35}$ Tamże, s. 116; Kalinkowski, Orygenes o Eucharystii, s. 65.

${ }^{36}$ Origenes, Contra Celsum VIII 55, SCh 150, 246, thum. S. Kalinkowski: Orygenes, Przeciw Celsusowi, wyd. 2, Warszawa 1986, 401.

${ }^{37}$ Origenes, In Lucam frag. 40(60), SCh 87, 490-492, tłum. S. Kalinkowski, PSP 56, 158; zob. S. Kalinkowski, Orygenes o Eucharystii, s. 67. 
znają i nie składają swoim bogom ofiar dziękczynnych:

„Niech więc Celsus, który nie zna Boga, składa ofiary dziękczynne demonom; my zaś dzięki składając Stworzycielowi wszystkich rzeczy za to, co otrzymaliśmy, z dziękczynieniem i modlitwą spożywamy chleby ofiarne, które przez modlitwę stają się ciałem świętym i uświęcającym"”38.

„Wymaga więc od nas Celsus wdzięczności wobec ziemskich demonów sądząc, że naszym obowiązkiem jest składanie im ofiar dziękczynnych. My wiemy dobrze, na czym polega wdzięczność [...]. Staramy się natomiast być wdzięczni wobec Boga, od którego «otrzymujemy wiele dobrodziejstw, zostaliśmy przez Niego stworzeni, cieszymy się Jego opieką» [...]. Posiadamy zresztą widzialny symbol naszej wdzięczności wobec Boga - chleb zwany Eucharystią"39.

Orygenes wierzy zatem w ofiarny i ekspiacyjny charakter Eucharystii oraz wspomina o ołtarzu ofiarnym, skrapianym drogocenną Krwią Chrystusa ${ }^{40}$. Aleksandryjski Katecheta przestrzega, że ponieważ w konsekrowanym modlitwą kapłańską chlebie eucharystycznym jest rzeczywiście obecny sam Chrystus, że jest to Jego ciało, winniśmy go przyjmować z jak największą czcią i szacunkiem oraz czystą, uświęconą i przygotowaną duszą, podobnie oczyszczeni, jak do słuchania słowa Bożego, po którym następuje celebrowanie Eucharystii:

„Nikt nie może słuchać Słowa Bożego, jeśli wpierw nie zostanie uświęcony, to znaczy jeśli nie będzie «święty ciałem i duchem» (1Kor 7, 34) i jeśli nie upierze swoich szat. Przecież niebawem zasiądzie do uczty weselnej, będzie spożywał ciało Baranka i pił kielich zbawienia. Niechaj nikt nie przychodzi na tę ucztę w brudnych szatach"41.

„Również tobie nadano owo Prawo, abyś przyjąwszy chleb mistyczny spożywał go «w czystym miejscu», to znaczy, abyś nie przyjmował tajemnic ciała Pańskiego do duszy splamionej i zbrukanej grzechami; powiedziano bowiem: «Ktokolwiek spożyje chleb lub wypije kielich Pański niegodnie, winien będzie ciała i krwi Pańskiej»" ${ }^{42}$

Zachęca też, by Eucharystię przyjmować uważnie i z troską, by żadna jej

${ }^{38}$ Origenes, Contra Celsum VIII 33, SCh 150, 246, thum. S. Kalinkowski, s. 401.

${ }^{39}$ Tamże VIII 57, SCh 150, 304, S. Kalinkowski, s. 415.

${ }^{40}$ Por. Origenes, In Jesu Nave hom. 2, 1, SCh 415, 56, PSP 34/2, 12: „Gdy zobaczysz, że buduje się kościoły, że ołtarze nie są skrapiane krwią zwierząt, lecz «drogocenną krwią Chrystusa» (1P 1, 19)".

${ }^{41}$ Origenes, In Exodum hom. 11, 7, SCh 321, 350, tłum. S. Kalinkowski, PSP 31/1, 262.

${ }^{42}$ Origenes, In Leviticum hom. 13, 5, SCh 287, 220, PSP 31/2, 176; zob. też: In Ps. 37 hom. 2, 6, PG 12, 1386: „Czy się nie obawiasz mieć udziału w Ciele Chrystusa, przystępując do Jego Eucharystii jakoby będąc czysty i niewinny, jakoby w tobie nie było nic niegodnego, i z tym wszystkim czy sądzisz, że unikniesz sądu Bożego?”. 
cząsta nie upadła i nie uległa zniszczeniu, podobnie jak przy słuchaniu słowa Bożego, by żaden jego szczegół nie uległ zapomnieniu:

„Wy, którzy macie zwyczaj uczestniczyć w boskich sakramentach, wiecie, że przyjmując Ciało Pańskie przechowujecie je z całą troską i czcią, aby nawet cząstka nie upadła, aby odrobina poświęconej ofiary nie uległa uszkodzeniu. Uważacie się za winnych, i słusznie, jeśli na skutek waszego niedbalstwa jakaś jej odrobina ulegnie zniszczeniu. Jeśli zaś dla zachowania Jego Ciała okazujecie tyle troski, i słusznie je okazujecie, to czyż sądzicie, że na mniejszą karę zasługuje lekceważenie Słowa Bożego niż Jego Ciała?"³.

Zaznacza wreszcie i zapewnia, że Eucharystia przyjęta z nieskalanym umysłem i czystym sumieniem przynosi wielkie korzyści duchowe:

„Gdy zatem idzie o Chleb Pański, kto go spożywa, odnosi korzyść, jeśli nieskalanym umysłem i z czystym sumieniem bierze z tego chleba" ${ }^{44}$.

Najpierw przynosi owoce wielkiego przebłagania oraz sprowadza życzliwość i przychylność Boga:

„Jeśli jednak odniesiemy to do wielkiej tajemnicy, to stwierdzisz, ze owa «pamiątka» przynosi skutek wielkiego przebłagania. Jeśli wrócisz do owego «chleba, który zstępuje z nieba i daje życie temu światu» (J 6, 33), do owego chleba pokładnego, «który Bóg ustanowił narzędziem przebłagania przez wiarę w Jego krwi» (Rz 3, 25), i jeśli zwrócisz uwagę na ową "pamiątkę», o której mówi Pan: «To czyńcie na moją pamiątkę» (Łk 22, 19), stwierdzisz, że jest to jedyna «pamiątka», która zyskuje ludziom przychylność Boga"45.

Zapewnia życie wieczne i wzrost duchowy:

„Kto zaś spożyje te pierwociny oraz skosztuje «chleba, który zstapił z nieba» $(\mathrm{J} 6,51)$, ten nie umrze, lecz będzie żył na wieki. Ten chleb bowiem, choć jest spożywany, trwa nieustannie, a nawet się powiększa. Jest więc wedle słów Apostoła «pokarmem duchowym» (1Kor 10, 3), który im bardziej jest spożywany, tym bardziej rośnie" ${ }^{\prime 46}$.

Gwarantuje też uświęcenie i łaski ${ }^{47}$. Jeżeli zaś ktoś gardzi Eucharystią, nie przyjmuje jej lub czyni to niegodnie, naraża się na surową karę Bożą, a nawet na potępienie, jak Judasz:

„Jeśli nie przyjmujemy ochoczo wielkich bogactw Pana naszego, jeśli nie

${ }^{43}$ Origenes, In Exodum hom. 13, 3, SCh 321, 384-386, PSP 31/1, 273.

${ }^{44}$ Origenes, Commentarius in Matthaeum XI 14, SCh 162, 342, thum. K. Augustyniak, ŹMT $10,97$.

${ }^{45}$ Origenes, In Leviticum hom. 13, 3, SCh 387, 208, PSP 31/2, 171.

${ }^{46}$ Origenes, In Numeros hom. 11, 6, SCh 442, 52, PSP 34/1, 110-111.

${ }^{47}$ Por. wyżej n. 36 i 38; zob. Origenes, In Matthaeum commmentarius, series 85, PG 13, 1735. 
spożywamy «chleba życia» (J 6, 35), jeśli nie spożywamy ciała Jezusa i nie pijemy Jego krwi, jeśli gardzimy ucztą naszego Zbawiciela, winniśmy wiedzieć, że Bóg ma «dobroć i surowość» $(\mathrm{Rz} 11,22)$ "»48.

„Kto niegodnie spożywa chleb Pana i pije jego kielich, ten sobie potępienie je i pije (1Kor 11, 27-29), bo jedna i ta sama moc znajdująca się w chlebie i w kielichu czyni dobro dla ustalonego dobrego usposobienia, dla złego zaś czyni zło [...]. Pozostałym uczniom chleb został dany dla zbawienia, Judaszowi zaś dla potępienia, ponieważ «po kromce» szatan w niego wstąpił"49.

Orygenes rozróżniał też w nauczaniu o Eucharystii dwa sposoby przyjmowania komunii eucharystycznej: komunii sakramentalnej (sacramentorum ritu), związanej z chlebem i winem, oraz komunii duchowej, która tych postaci nie potrzebowała ${ }^{50}$. „Pierwszą rezerwowano dla chrześcijan bez roszczeń kulturowych [...], dla intelektualistów zaś «duchowych» rezerwowano komunię «w Duchu», ponieważ jest bardziej wzniosła i bezpośrednio nastawiona na ową prawdziwą komunię duchowa, która stanowi cel każdego żyjącego" "51.

Celowo przytoczyliśmy więcej wypowiedzi Orygenesa, bo znajdują się w nich najstarsze przejawy systematycznej teologii Eucharystii; charakteryzują je zaś trzy cechy: typologiczna interpretacja Starego Testamentu - niektóre jego przedmioty lub wydarzenia (np. manna czy ofiara Melchizedeka) są figurami Eucharystii; odnosi się je na równi (jeśli nie więcej) do sakramentu słowa Bożego i do Eucharystii; przejawia się w nich ogólnie mentalność platońska, dostrzegająca w rytach sakramentalnych realizacje rzeczywistości duchowych ${ }^{52}$.

Dwaj późniejsi przedstawiciele Szkoły Aleksandryjskiej - św. Atanazy i Cyryl Aleksandryjski w nieco innej perspektywie głosili katechezę o Eucharystii: w związku z toczącymi się wówczas sporami chrystologicznymi z Chrystusem wcielonym Słowem, prawdziwym Bogiem i człowiekiem oraz z Chrystusem posiadającym w jednej hipostazie dwie natury - boską i ludzką, mniej eksponując nie kwestionowaną wówczas przez nikogo rzeczywistą obecność Chrystusa w postaciach eucharystycznych; rzecz ciekawa, że żaden z nich nie użył terminu ,eucharystia” na oznaczenie Mszy św. lub Ciała i Krwi Pańskiej.

${ }^{48}$ Origenes, In Lucam hom. 38, 6, SCh 87, 448, PSP 36, 142.

${ }^{49}$ Origenes, Commentarius in Joannem XXXII 309, SCh 385, 318-320, thum. S. Kalinkowski, PSP 28, 166.

${ }^{50}$ Por. Origenes, In Numeros hom. 16, 9, SCh 442, 262, PSP 34/1, 170: „Mówimy o sobie, że «pijemy krew Chrystusa» nie tylko w obrządku sakramentalnym, ale i wówczas, gdy przyjmujemy Jego słowa, w których jest życie - zgodnie z tym, co On sam mówi: «Słowa, które Ja wam powiedziałem, są duchem i życiem» (J 6, 63).

${ }^{51}$ Qualizza, Inicjacja chrześcijańska, 128.

${ }^{52}$ Por. Camelot, L'Eucharistie dans l'Ecole d'Alexandrie, s. 84. 
Św. Atanazy Aleksandryjski - główny protagonista i obrońca bóstwa Chrystusa w sporach ariańskich, choć szedł śladami eucharystycznej tradycji aleksandryjskiej Klemensa i Orygenesa, to nie wypowiedział się nigdzie szerzej w specjalnym traktacie, a nawet katechezie, na temat Eucharystii, ale tylko przygodnie w swoich pismach polemicznych, a zwłaszcza w swoich pasterskich listach wielkanocnych ${ }^{53}$. Terminu „eucharystia” użył tylko dwukrotnie na oznaczenie składanego Bogu dziękczynienia ${ }^{54}$, zaś Mszę św. nazywał „tajemnicami” (mysteria) lub synaksq, a postacie eucharystyczne - „Ciałem Pańskim”, „Ciałem i Krwią Pana naszego Jezusa Chrystusa”, „Chlebem Anielskim”, „Chlebem Niebieskim”, „Niebieskim Pokarmem” itd. Zgodnie z tradycją aleksandryjską przyjmował rzeczywistą obecność Chrystusa w chlebie i winie po konsekracyjnych słowach (epiklezie) kapłana, ale nie zajmował się bliżej wyjaśnianiem samej transsubstancjacji, relacji Mszy św. do Ofiary krzyżowej, czy też ukazywaniem ich ofiarnego charakteru. Na jego wiarę w rzeczywistą obecność Chrystusa w chlebie i winie po konsekracji wskazuje m.in. następującą wypowiedź:

„Zobaczysz Lewitów niosących chleby oraz kielich wina, i składających je na ołtarzu. Dopóki jednak nie wygłosi się [nad nimi] modlitw i wezwań, dopóty nie ma tam nic innego, jak tylko chleb i kielich. Kiedy zaś zostaną [nad nimi] wygłoszone wielkie i cudowne modlitwy, wtedy chleb staje się Ciałem, a kielich Krwią Pana naszego Jezusa Chrystusa [...]. Przystapmy zatem do celebrowania Tajemnic. Ten chleb i kielich przed modlitwami i wezwaniami są czymś zwyczajnym, ale kiedy zostaną [nad nimi] wygłoszone wielkie modlitwy i święte wezwania, Słowo zstępuje na chleb i kielich, te stają się Jego Ciałem i Krwią"s5.

Jest to fragment jakiejś niezachowanej, a cytowanej przez Eutychiusza (VI w.) atanazjańskiej katechezy mistagogicznej do neofitów. Ostatnie jego zdanie, zaczerpnięte niemal dosłownie z Euchologionu Serapiona z Thmuis, nawiązuje do starej, rozpowszechnionej również w Egipcie, tzw. Logosepiklese, przypisującej dominującą rolę przy przeistoczeniu, podobnie jak wcześniej przy wcieleniu, Logosowi $(\text { Słowu })^{56}$. W związku z tak pojmowaną epiklezą

${ }^{53}$ Por. S. Longosz, Święty Atanazy o Eucharystii, w: Pokarm nieśmiertelności, s. 77-88; Camelot, L'Eucharistie dans l'Ecole d'Alexandrie, s. 85-86; P. Batiffol, L'Eucharistie: la présence réelle et la transsubstantation, Paris 1905, 318-325; Betz, Die Eucharistie in der Zeit der griechischen Väter, s. 88, 95-96, 121-124, 283-284, 291-292; tenże, HDG IV/4a 68-69; G. Bareille, DThC V 1140-1141.

${ }^{54}$ Por. Athanasius, Apologia contra Arianos 7 i Historia Arianorum 39, PG 25, 262B i 704A; zob. G. Müller, Lexicon Athanasianum, Berlin 1952, 581-582; Longosz, Św. Atanazy o Eucharystii, s. 77.

${ }^{55}$ Athanasius, Ad nuper baptizatos, PG 26, 1325 - wszystkie teksty Atanazego thum. S. Longosz; zob. Eutychius, Sermo de sancta Eucharistia, PG 86, 2401.

${ }^{56}$ Por. Euchologium Serapionis 13, 15, ed. Funk II 174-175: „Niech zstąpi Duch Prawdy, Święte Twoje Słowo [Logos] na ten chleb, aby chleb stał się Ciałem Słowa oraz na ten kielich, aby kielich stał się Krwią Prawdy”. 
i przekonaniem, Atanazy przypomina swoim wiernym, że podczas Eucharystii spożywają Ciało Logosu i piją drogocenną Krew Logosu, że w odróżnieniu od starotestamentalnej Paschy, kiedy spożywano baranka, teraz spożywają Ciało samego Logosu Ojca, a mogą to czynić nawet codziennie. Ciało eucharystyczne jest ciałem „duchowym” Chrystusa Zmartwychwstałego, i z tej racji jest też pokarmem duchowym i zadatkiem nieśmiertelności:

„Wtedy świętowali nierozumnie przez spożywanie mięsa baranka i namaszczenie jego krwią progów, teraz zaś spożywamy Słowo Ojca (Patris Verbum comedimus) i znaczymy wargi naszych serc Krwią Nowego Testamentu, wyznając, że dostapiliśmy łaski przez Zbawiciela [...]. Sam bowiem nasz Zbawiciel, przechodząc od tego, co było w figurze, do tego, co jest duchowe, obieca! im (Apostołom), że nie będą już spożywać mięsa baranka, ale Jego samego, aby mówił: «Bierzcie, jedzcie i pijcie: to jest ciało moje i krew moja» (Mt 26, 26-28) ${ }^{57}$ [...]. Pan nasz i Zbawiciel Jezus Chrystus jest chlebem anielskim oraz staje się pokarmem świętych, jak sam mówił: «Jeśli nie będziecie spożywać mego ciała i nie będziecie pić mojej krwi [...]» (J 6, 54)"s8.

„[...] jesteśmy karmieni pokarmem życia i orzeźwiamy naszą duszę Jego drogocenną Krwią, jakoby wodą z jakiegoś źródła [...]. I nie tylko teraz (Wielkanoc) ktoś gasi swoje pragnienie, gdy się do niej zbliża, ale także,. ilekroć ktoś chce, pozwala mu się chętnie, by się zbliżył do Zbawiciela"59.

„Również i teraz, moi ukochani, obchodzimy święta wielkanocne, ale zbliżmy się do nich nie jak do dnia smutku lecz raczej radości w Chrystusie, którym się codziennie karmimy (in Christo quo quotidie vescimur)" ${ }^{\prime 60}$.

Charakter ofiarny Eucharystii we Mszy św. starał się Atanazy zaznaczyć m.in. w następujących słowach:

„Teraz ofiarujemy nie zwyczajnego materialnego baranka, ale Tego prawdziwego, który się za nas ofiarował, Pana naszego, Jezusa Chrystusa, który prowadzony jak owca na zabicie i niemy jak baranek wobec strzygącego (Iz $53,7)$, oczyszcza nas swoją drogocenną Krwią, przemawiającą o wiele mocniej niż krew Abla (Hbr 12, 24)"'61.

Zachęcając wiernych w swoich Listach światecznych do przyjmowania Eucharystii w Komunii Świętej Atanazy wskazywał na jej skutki i owoce, wśród których najczęściej wymieniana jest obietnica zmartwychwstania i życia wiecznego oraz wspólna z aniołami i świętymi uczta niebiańska:

\footnotetext{
${ }^{57}$ Athanasius, Epistula festalis 4, 3 i 4, PG 26, 1377 i 1379.

${ }^{58}$ Tamże 1, 5, PG 26, 1363.

${ }^{59}$ Tamże 5, 1, PG 26, 1379-1380.

${ }^{60}$ Tamże 13, 7, PG 26, 1418

${ }^{61}$ Tamże 1, 9, PG 26, 1365.
} 
"Chleb ten, Bracia moi, jest nie tylko pokarmem sprawiedliwych, i nie tylko święci na ziemi żywią się takim chlebem i krwią (tali pane vescuntur et sanguine), lecz będziemy go spożywać również w niebie: On jest bowiem w równy sposób pokarmem, jak i Panem wszystkich duchów niebieskich i aniołów, rozkoszą wszystkich władz niebieskich; będzie wszystkim dla wszystkich, a ze swej łaskawości będzie się litował nad wszystkimi. Pan najpierw nam dał chleb aniołów, teraz zaś obiecuje go tym, którzy razem z Nim cierpieli doświadczenia, mówiąc: «Obiecuję wam, jak Mi obiecał mój Ojciec, Królestwo, abyście w Królestwie moim jedli i pili przy moim stole oraz żebyście zasiadali na 12 tronach, sądząc 12 pokoleń Izraela» (Łk 22, 29-30). Z racji godności owej uczty (cenae), Bracia moi, jaka będzie zgodność i radość tych, którzy będą jeść przy owym stole. Będą oczywiście spożywać potrawy, ale nie takie, które organizm musi wydalać, ale takie, które dają życie wieczne. Kto będzie tak szczęśliwy, by sobie zasłużyć na zaproszenie na ową boską ucztę? Szczęśliwy zaś ten, kto będzie spożywał chleb w Królestwie Twoim (Łk 14, 15)"’2.

Kilka wreszcie cennych szczegółów dotyczących sprawowania Eucharystii w poł. IV wieku w Aleksandrii i jej okolicach przekazał nam Atanazy przy tłumaczeniu się z oskarżenia przez arian ${ }^{63}$, że nakazał napaść na Ischyrasa celebrującego Mszę św. w prywatnym domu w Mareocie, wywrócić jego ołtarz, zniszczyć kielich ofiarny i spalić księgi liturgiczne, za co został deponowany w 355 r. przez synod w Tyrze.

Czwartym wreszcie przedstawicielem Szkoły Aleksandryjskiej, w którego nauczaniu teologia Eucharystii, według badaczy, miała osiagnąć swój szczyt, był Cyryl Aleksandryjski ${ }^{64}$. I on nie napisał jednak żadnego traktatu o Eucharystii, ale uczył o niej tylko przygodnie w swoich komentarzach biblijnych oraz w pismach dogmatycznych i polemicznych. Nie nazywał jej jednak nigdy „eucharystią”, ale zgodnie z późniejszą tradycją aleksandryjską - „eulogią" lub „eulogią mistyczną”, a uczestnicząc w sporach chrystologicznych

${ }^{62}$ Tamże 7, 8, PG 26, 1395; zob. także tamże 7, 5, PG 26, 1393; Epistula ad Serapionem 4, 19 , PG 26, 665C-668A.

${ }^{63}$ Por. Athanasius, Apologia contra arianos 11-12 i 17 oraz 83, PG 25, 265-269 i 276 oraz 396397, tłum. J. Ożóg, PSP 21, 104-105 i 108 oraz 161.

${ }^{64}$ O Eucharystii u Cyryla Aleksandryjskiego zob.: M. Michaud, Saint Cyrille d'Alexandrie et l'Eucharistie, „Revue Internationale de Théologie” 10 (1902) 599-614, 675-692; J. Mahé, L'Eucharistie d'après saint Cyrille d'Alexandrie, RHE 8 (1907) 677-696; A. Struckmann, Die Eucharistielehre des heiligen Cyrill von Alexandrien, Paderborn 1910; H. du Manoir, Dogme et spiritualité chez saint Cyrille d'Alexandrie, Paris 1944, 185-218; Batiffol, L'Eucharistie: la présence réelle et la transsubstantiation, s. 454-480; Camelot, L'Eucharistie dans l'Ecole d'Alexandrie, s. 86-91; Betz, Die Eucharistie in der Zeit der griechischen Väter, s. 313-317; tenże, HDG IV/4a 112-115; G. Bareille, DThC V 1162-1165; J.M. Szymusiak, SWP 488-489; Starowieyski, Ojcowie Kościoła Wschodniego o Eucharystii, s. 54-61; S. Longosz, Mistyczna Eulogia w nauczaniu Cyryla Aleksandryjskiego, w druku. 
i w polemice z Nestoriuszem, uściślił jej teologię, podkreślając mocno, że jest ona Ciałem i Krwią Słowa (Logosu) pochodzącego od Ojca.

Podobnie, jak jego aleksandryjscy poprzednicy, przyjmował rzeczywista obecność Chrystusa w postaciach eucharystycznych, ucząc, że następuje ona po tajemniczej przemianie (metapoiein) chleba i wina w Ciało i Krew Chrystusa, której dokonuje Wszechmocny Bóg, czego dowodem są słowa Zbawiciela: „To jest Ciało moje, to jest Krew moja”. Chleb i wino nie są już po niej tylko zewnętrznymi figurami (typoi), ale zostały przemienione w prawdziwe Ciało i Krew Chrystusa. Ciało bowiem Chrystusa zostało uświęcone mocą Słowa, z którym się zjednoczyło, a w następstwie sprawiło, że uświęca ono i jednoczy się z tymi, którzy je przyjmują. Chrystus jest obecny pod każdą cząstką Eulogii i to trwale, dlatego też dzieląc ją nie dzielimy bynajmniej Chrystusa, ale jest On cały w każdej z nich; ta Jego obecność w Eulogii nie jest tylko chwilowa, w momencie przyjmowania, ale permanentna; nie dostrzegamy jej zmysłami, ale tylko w sposób mistyczny ${ }^{65}$ :

„Jezus jest bowiem z natury życiem jako zrodzony z żyjącego Ojca. A w nie mniejszym stopniu życiodajne jest także święte Jego Ciało, złączone i w pewien niewysłowiony sposób zjednoczone ze Słowem, dzięki któremu wszystko żyje. Dlatego uważamy, że jest to Ciało Słowa i że ze Słowem stanowi jedno. Są bowiem nierozłączne po wcieleniu, oprócz tego jednego tylko, że, jak wiemy, Słowo, które pochodzi od Ojca, i świątynia (ukształtowana w łonie) Dziewicy nie są tym samym z natury. Ciało nie jest współistotne ze Słowem Bożym, jest z Nim wszakże jednym przez współbycie i niewysłowione zjednoczenie. A skoro ciało Zbawiciela stało się życiodajne jako zjednoczone z Tym, który jest z natury życiem, to znaczy ze Słowem Bożym, to i my, gdy Je spożywamy, mamy w sobie życie, gdyż i my jesteśmy zjednoczeni z tym Ciałem tak, jak On z mieszkającym w nim Słowem"66.

„Jeśli ktoś nie wyznaje, że ciało Pana jest ciałem dającym życie i własnym ciałem samego Słowa z Boga Ojca, ale ciałem kogoś innego niż On, jakby złączonym ze Słowem godnością, albo mówi, że jest ono jedynie jakby Bożym mieszkaniem, a nie raczej, jak powiedzieliśmy, ciałem dającym życie, ponieważ stało się ono ciałem własnym Słowa mogącego wszystko ożywiać - niech będzie wyklęty"67.

Ciałem zatem Słowa (Logosu) oznacza Cyryl Jego człowieczeństwo; to Ono jest przekazicielem życia, i dlatego człowieczeństwo Słowa jest

${ }^{65}$ Por. Cyrillus Alexandrinus, In Joannem XI, PG 74, 528B; XII, PG 74, 660BC; In Matthaeum 26, PG 72, 452; In Lucam 19, PG 72, 912; Epistula ad Calosyrium, PG 76, 1076A; Adversus Nestorium 4-7, PG 76, 189-208; De adoratione 7, PG 68, 501.

${ }^{66}$ Cyrillus Alexandrinus, In Joannem IV 2, PG 73, 577-580, thum. K. Augustyniak, w: Starowieyski, Ojcowie Kościoła Wschodniego o Eucharystii, s. 56-57.

${ }^{67}$ Cyrillus Alexandrinus, Anathematismi 11, thum. A. Baron, ŹMT 24 (DSP 1), 157. 
człowieczeństwem Syna Bożego, jest z Nim „istotowo” zjednoczone. A więc komunia z ciałem Chrystusa w Eucharystii jest uczestnictwem w samym życiu Słowa; Jego człowieczeństwo jest „,narzędziem” bóstwa. Tajemnice wcielenia i tożsamość Słowa stanowią moc Eucharystii ${ }^{68}$.

Cyryl Aleksandryjski przypomina również, że Eucharystia jest czystą i bezkrwawą ofiara, w której ofiarowany jest Chrystus. Ofiarę tę składa się każdego dnia po całym świecie i trwać będzie aż do skończenia świata, heretycy jednak nie mają prawa do jej składania:

„Wszędzie kościoły, pasterze, nauczyciele, wykładowcy, wprowadzają w tajemnice i święte ołtarze, i Baranek składany jest w sposób rozumny przez świętych kapłanów w Indiach i w Etiopii" ${ }^{69}$.

„Malachiasz mówi o pojawieniu się naszego Zbawiciela i o tym, że będzie wtedy złożona Bogu ofiara czysta i bezkrwawa. Ustaną wtedy występki wszystkich, grzech zostanie zniesiony, a mieszkańcy ziemi zostaną wtedy przekształceni do nowego życia"70.

Cyryl Aleksandryjski często również wskazywał na liczne owoce, jakimi Eulogia Mistyczna obdarza tych, którzy ją przyjmują ${ }^{71}$. Oprócz tych tradycyjnie wymienianych, jak uświęcenie i gwarantowanie życia wiecznego, Cyryl bardzo mocno podkreślał uczestnictwo i zjednoczenie z Chrystusem, i to nie tylko w sposób duchowy (pneumatikos), ale i fizyczny, cielesny (somaticos), na podobieństwo dwóch kawałków wosku, które rozgrzane na ogniu, stapiają się w jedno fizycznie (physike henotes), lub na podobieństwo zaczynu, który zakwasza całe ciasto, sprawiając, że Chrystus jest w nas, a my w Chrystusie:

„«Kto spożywa moje Ciało - mówi - i Krew moją pije, trwa we mnie, a ja w nim». Kiedy ktoś stopi razem dwa kawałki wosku, ujrzy, że jeden kawałek jest całkowicie w drugim. W podobny sposób, sądzę, i ten, kto przyjmuje Ciało Chrystusa, naszego Zbawiciela, i kto pije cenną Krew Jego, stanie się, jak On sam to mówi, jednym z Nim, tak z Nim zlany i złączony przez to uczestnictwo, że sam będzie w Chrystusie, a Chrystus będzie w nim. Mniej więcej tej samej nauki udzielił nam Chrystus także w Ewangelii według Mateusza, gdzie powiada: «Królestwo niebieskie podobne jest do zaczynu, który pewna kobieta wzięła i włożyła w trzy miary mąki, aż się wszystko zakwasiło»

${ }^{68}$ Por. Qualizza, Inicjacja chrześcijańska, s. 128.

${ }^{69}$ Cyrillus Alexandrinus, In Sophoniam 2, 39, PG 71, 1008, tłum. M. Starowieyski, Ojcowie Kościoła Wschodniego, s. 61.

${ }^{70}$ Cyrillus Alexandrinus, In Malachiam 12, PG 72, 297, tłum. M. Starowieyski, jak wyżej, s. 60; zob. też: In Lucam 5, 14, PG 72, 905; Glaphyra in Leviticum, PG 69, 552; Adversus anthropomorphistas 12, PG 76, 1097; De adoratione 10, PG 68, 725.

${ }^{71}$ Por. np. Cyrillus Alexandrinus, In Joannem XI 11, PG 74, 556-577; XII, PG 74, 677; In Matthaeum 26, PG 72, 452; In Lucam 22, PG 72, 905; Adversus Nestorium 4, PG 76, 189-208; Anathematismi 2, PG 77, 121; Apologeticus contra Orientales II, PG 77, 373, itd. 
(Mt 13, 3) [...]. Jak mówi św. Paweł, «że odrobina kwasu całe ciasto zakwasza» (1Kor 5, 6), tak i najmniejsza cząstka Eulogii łączy ze sobą całe nasze ciało i napełnia je własną mocą. W ten to sposób Chrystus jest w nas, a my w Nim, bo prawdziwie można powiedzieć, że zaczyn jest w całym cieście, a stosując te same słowa - także i ciasto jest w całym zaczynie"72.

„«Chleb, który łamiemy, czyż nie jest udziałem w Ciele Chrystusa? Ponieważ jeden jest chleb, przeto my liczni, tworzymy jedno ciało. Wszyscy bowiem bierzemy z tego samego chleba» (1Kor 10, 16-17). Ciało człowieka, jeśli chodzi o własną naturę, nie może być ożywicielem. Również zwyczajna krew ludzka sama przez się i według siebie nie ma siły ożywienia. Ożywia natomiast Ciało Chrystusa i droga Krew, bo Bóg tylko może dawać życie temu, co życia potrzebuje. A więc Bogiem jest Chrystus, bo Ciało Jego daje życie" 73 .

„«Chlebem, który Ja dam, jest moje Ciało za życie świata» (J 6, 51). Pan nasz, Jezus Chrystus, bowiem żywi nas na życie bez końca przykazaniami pobożności i błogosławieństwem uczty mistycznej. On bowiem sam z siebie jest ową boską manną, prawdziwie dającą życie. A ten, kto ją pożywa, wolny jest od zepsucia i ominie go śmierć, której nie uniknęli ci, którzy jedli mannę widzialną. Nie jest to bowiem tylko figura zbawienna, ale stanowi wyraz prawdy"74.

Nie bez celu przytoczyliśmy wyżej wiele konkretnych wypowiedzi na temat Eucharystii czterech głównych przedstawicieli Szkoły Aleksandryjskiej, aby jak najlepiej przybliżyć, jak w niej ją przy inicjacji rozumiano, celebrowano, przyjmowano, i jakie owoce jej przypisywano. Ujmuje to syntetycznie Marino Qualizza: ,Wkład Szkoły Aleksandryjskiej, rozciągnięty na przestrzeni kilku wieków, jest znaczący, ponieważ dostarczył przynajmniej dwa możliwe wyjaśnienia problemu. Wymiar „duchowy” Eucharystii powinien zawsze pozostawać na pierwszym planie, zgodnie z tym, co zostało powiedziane w J 6, 63: „Duch daje życie; ciało na nic się nie przyda [...]. Drugie wyjaśnienie jest nie mniej ważne. Uwydatniona w nim została moc zbawcza Eucharystii na fundamencie wcielenia i prawdziwości człowieczeństwa Jezusa, zawsze widzianego w jedności osobowej Słowa, początku każdego zbawienia i ubóstwienia"75.

$\mathrm{Z}$ tej krótkiej prezentacji dociera do nas cenny wizerunek Eucharystii. I chociaż o Eucharystii twórcy Szkoły Aleksandryjskiej nie wszystko powiedzieli, to została zbudowana przez nich nośna struktura, pozostająca

${ }^{72}$ Cyrillus Alexandrinus, In Joannem IV 2, PG 73, 584BD, tłum. K. Augustyniak, w: Starowieyski, Ojcowie Kościoła Wschodniego, s.57-58.

${ }^{73}$ Cyrillus Alexandrinus, Oratio ad Arcadiam et Marinam augustas, PG 76, 1281, thum. W. Kania, PSP 18, 125.

${ }^{74}$ Cyrillus Alexandrinus, Glaphyra in Pentateuchum, PG 69, 465, thum. M. Starowieyski, Ojcowie Kościoła Wschodniego, s. 60.

${ }^{75}$ Qualizza, Inicjacja chrześcijańska, s. 129. 
w harmonii z Objawieniem i może być ona inspiracją w działalności katechetycznej i ewangelizacyjnej.

\section{EUCHARYSTIA A MISJA KATECHETYCZNA}

Z ideowej spuścizny katechetycznej Szkoły Aleksandryjskiej płyną dla dzisiejszej praktyki katechetycznej ważne wskazania. Po pierwsze, jej wkład jest znaczący dlatego, ponieważ, jak zauważa Marino Qualizza, dostarczył ważnego wyjaśnienia problemu Eucharystii, zwłaszcza jej wymiaru duchowego. Jednakże znaczenie duchowe Eucharystii nie może prowadzić jedynie do zwyczajnego uduchowienia człowieka, ale do sakramentalnego uwypuklenia tej największej tajemnicy ${ }^{76}$. Bezcenne jest ponadto uwrażliwienie na moc zbawczą Eucharystii, dla której sprawą prymarną było wcielenie i prawdziwość człowieczeństwa Jezusa, widzianego zawsze w jedności osobowej Słowa. Ważnym było także zainicjowanie praktyki, że najlepszym dniem celebrowania Eucharystii jest niedziela, choć z upływem czasu sprawowano ją również w dni powszednie. Kluczem organizacyjnym do tego były początkowo wyjątkowe okoliczności, jak rocznica męczeństwa, później wybrane dni tygodnia, by u schyłku starożytności chrześcijańskiej uczynić z tego praktykę codzienną ${ }^{77}$. Po czwarte można potwierdzić na podstawie zachowanych źródel, że uczestnictwo w niedzielnej Eucharystii było od samego początku traktowane jako nieodzowny element chrześcijańskiego życia ${ }^{78}$, a uczestnictwo w Eucharystii wiązało się z jej przyjmowaniem, co wymagało właściwego przygotowania duchowego ${ }^{79}$. Za świętego uznawano chrześcijanina, który nie był w kolizji z dyscypliną gminy chrześcijańskiej oraz nie ciążyła na nim żadna dyscyplinarna kara. Z czasem „,do Komunii świętej mógł z czystym sumieniem przystąpić ortodoksyjny chrześcijanin, żyjący według moralności wynikającej z Ewangelii" "80.

Przekaz Aleksandryjskiej Szkoły katechetycznej na temat Eucharystii winien trwać w edukacji religijnej we współczesnych szkołach, posiłkując się nauczaniem Jana Pawła II w encyklice Ecclesia de Eucharistia z 2003 roku: „To, co dokonało się na terenach starożytnej chrystianizacji w dziedzinie sztuki kościelnej i dyscypliny liturgicznej, rozwija się [...], dostosowując się do zmieniających się warunków czasu i przestrzeni. Eucharystia zapewnia pokarm nie tylko pojedynczym osobom, lecz całym ludom, i kształtuje kultury inspirujące się chrześcijaństwem”81. Znacząca jest jednak przestroga: „Potrze-

\footnotetext{
${ }^{76}$ Por. tamże.

${ }^{77}$ Por. Żurek, Wczesnochrześcijańska pobożność eucharystyczna, s. 332.

${ }^{78}$ Tamże.

${ }^{79}$ Już najstarsze pismo chrześcijańskie Didache $(10,6)$ stwierdza krótko: „Kto święty niech przystąpi, kto nim nie jest, niech czyni pokutę".

${ }^{80}$ Żurek, Wczesnochrześcijańska pobożność eucharystyczna, s. 333.

${ }^{81}$ Joannes Paulus II, Litterae encyclicae „Ecclesia de Eucharistia” 51, thum. pol.: Jan Paweł II,
} 
ba jednak, aby to ważne dzieło przystosowania było spełniane z nieustanna świadomością niewypowiedzianej tajemnicy, wobec której staje każde pokolenie. «Skarb» jest zbyt wielki i cenny, żeby ryzykować jego zubożenie czy też narażenie na szwank przez eksperymenty, bądź praktyki wprowadzane bez uważnej oceny ze strony kompetentnych władz kościelnych"82.

Co z tej nauki zostało w dzisiejszej posłudze katechetycznej? Wydaje się, że w warstwie deklaratywnej bardzo dużo, niestety nieco mniej, w codziennej praktyce. Na synodzie biskupów, dotyczącym Eucharystii ustalono w 2007 r., że należy ją przeżywać jako tajemnicę wiary autentycznie celebrowaną, w pełnej świadomości, że intellectus fidei $\mathrm{w}$ Kościele pozostaje w pierwotnym związku z czynnością liturgiczną. W tym zaś zakresie refleksja teologiczna nie może nigdy abstrahować od porządku sakramentalnego, ustanowionego przez samego Chrystusa ${ }^{83}$. Jest to bardzo ważna informacja dla dzisiejszego przekazu katechetycznego, który ulegając czasem modnym tendencjom pedagogicznym, zmaga się z pokusą porzucenia kontekstu liturgicznego w nauczaniu o Eucharystii. $Z$ drugiej zaś strony akcja liturgiczna nigdy nie może być rozważana powierzchownie, w oderwaniu od tajemnicy wiary. Źródłem naszej wiary i liturgii eucharystycznej jest bowiem samo wydarzenie: dar, jaki Chrystus uczynił z samego siebie w tajemnicy paschalnej ${ }^{84}$.

Do Boga możemy prowadzić katechizowanych jedynie dlatego, że On jako pierwszy wyszedł szukać człowieka; pozwala się także nieustannie odnajdywać w Eucharystii. Na tym właśnie odcinku katecheza ma wiele do zrobienia. Często przemilczając najważniejsze jej konsekwencje, mimo iż jest powołana do budowania wspólnoty wierzących, szkodzi intencji Zbawiciela. Samo sprawowanie sakramentu Eucharystii bardzo często utwierdza świadomość jego absolutnie indywidualnego charakteru, z zagubieniem wymiaru eklezjalnego, pojednania się z Kościołem, jako znaku jednoczącej misji Kościoła wobec świata. Kształtowanie wrażliwości na celebrację Eucharystii, w stylu przekazanym przez aleksandryjską starożytną szkołę katechetyczną, może również kształtować świadomość eklezjalną i prowadzić do jej rozwoju.

Mówiąc o drogach wychowania świadomości eucharystycznej nie można jednak ograniczyć się do katechezy sakramentów, z których wypływa i wokół których kształtuje się życie chrześcijańskie. Oczywiście, wychowanie takie zakłada przekaz dotyczący całokształtu Objawienia, szczególnie w oparciu o Pismo Swięte, oraz informację o elementach doktrynalnych, kontestowanych

Encyklika o Eucharystii w życiu Kościoła „Ecclesia de Eucharistia”, Tarnów 2003, Wydawnictwo „Biblos”.

${ }^{82}$ Tamże.

${ }^{83}$ Por. Benedictus XVI, Adhortatio Apostolica postsynodalis „, Sacramentum caritatis” (22 II 2007) 34, AAS 99 (2007) 133, thum. pol.: Benedykt XVI, Posynodalna adhortacja apostolska ,Sacramentum caritatis" do biskupów do kapłanów i diakonów, do zakonników i zakonnic oraz wszystkich wiernych o Eucharystii, źródle i szczycie życia i misji Kościoła, Watykan 2007.

${ }^{84}$ Tamże. 
obecnie przez laickie środowiska. Ten też wymiar powinien być szeroko uwzględniony w kolejnych publikacjach.

Artykuł omawiający Eucharystię jako centrum celebracji chrześcijańskiej skupił się na jednym z naczelnych celów całej katechezy - na kształtowaniu świadomości wspólnotowej. W procesie wychowawczym chodzi o dostrzeżenie przez uczniów wewnętrznego związku między przeżywaną coraz częściej przez młodych pustką duchowa, a istotą i misją Kościoła, jako znaku i narzędzia jedności oraz wzorcowej wspólnoty ludzkiej, zarówno w wymiarze wertykalnym jak i horyzontalnym. Brak poczucia ważności Eucharystii oraz niewłaściwy sposób jej celebrowania w Kościele Chrystusowym, musi być dostrzeżony jako sprzeczny z jego istotą i misją ewangelizacji jako służby światu na wzór Chrystusa Sługi.

$* * *$

Życie ludzkie jest ciagłym poszukiwaniem piękna wiary, która prowadzi do Boga w Eucharystii. Rozjaśnianie znaczenia Eucharystii posiada aktualnie wielkie znaczenie dla osób, które tracą żywy kontakt z Bogiem. Dziedzictwo nauczania o Eucharystii z początków chrześcijaństwa do dziś jest bezcenne, ponieważ pozwala nadal tak wielu ludziom poszukującym Boga znaleźć właściwą ścieżkę, aby dojść do wiary.

\section{THE EUCHARIST AS A CENTER OF CHRISTIAN CELEBRATION IN THE SPIN OF THE ALEXANDRIAN CATECHETICAL SCHOOL}

\section{(Summary)}

In connection with noticed today decrease of meaning and number of participants of the Eucharistic celebration and disappearance its common and conscious experiences, author of the article in searching inspirations to solve this situation appeals to the Early Christian tradition of the Alexandrian Catechetical School of the III-V century. In this, exactly, school belief in real presence of Christ in the celebration of the Holy Eucharist and awareness of its consequences was a key value. The faced problem is figured out at the three chapters: 1 . Eucharist a celebrated mystery. 2. The Alexandrian Catechetical School in work for modern school of Eucharist (talked through multiple statements, science about Eucharist of aspect of real presence, sacrifice and fruits of experience four most famous its leaders: Clement of Alexandria, Origen of Alexandria, Athanasius of Alexandria and Cyril of Alexandria); 3. The Eucharist and catechetical mission. 